Georgetown University Law Center

Scholarship @ GEORGETOWN LAW

2021

\title{
Testa, Crain, and the Constitutional Right to Collateral Relief
}

Carlos Manuel Vázquez

Georgetown University Law Center, vazquez@law.georgetown.edu

Stephen I. Vladeck

University of Texas at Austin School of Law, svladeck@law.utexas.edu

This paper can be downloaded free of charge from:

https://scholarship.law.georgetown.edu/facpub/2359

https://ssrn.com/abstract=3792511

Florida Law Review Forum, Vol. 72, Pp. 10-21, 2021.

This open-access article is brought to you by the Georgetown Law Library. Posted with permission of the author. Follow this and additional works at: https://scholarship.law.georgetown.edu/facpub

Part of the Constitutional Law Commons, Courts Commons, Criminal Procedure Commons, and the Supreme Court of the United States Commons 


\title{
TESTA, CRAIN, AND THE CONSTITUTIONAL RIGHT TO COLLATERAL RELIEF
}

\author{
Carlos M. Vázquez" and Stephen I. Vladeck ${ }^{* *}$
}

In Montgomery v. Louisiana, ${ }^{1}$ the U.S. Supreme Court held that state prisoners have a constitutional right to relief from continued imprisonment if the prisoner's conviction or sentence contravenes a new substantive rule of constitutional law. ${ }^{2}$ Specifically, the Court held that prisoners with such claims are constitutionally entitled to collateral relief in state court - at least if the state courts are open to other claims for collateral relief on the ground that their continued imprisonment is unlawful. ${ }^{3}$ In our article, The Constitutional Right to Collateral PostConviction Relief, we argued that, under two lines of Supreme Court decisions interpreting the Supremacy Clause, states are in fact required to open their courts to claims based on new substantive rules of constitutional law even if the states' courts do not have jurisdiction to entertain collateral claims as a matter of state law. ${ }^{4}$

In their recent article, State Jurisdictional Independence and Federal Supremacy, Professors Ann Woolhandler and Michael G. Collins dispute our reliance on these two lines of Supremacy Clause cases. ${ }^{5}$ Specifically, they argue that the Constitution, as originally understood and as interpreted throughout the nineteenth century, gives states discretion to control the jurisdiction of their own courts. ${ }^{6}$ This response briefly discusses Professors Woolhandler and Collins's treatment of these two lines of Supremacy Clause cases, and explains why our previous reading of Montgomery holds.

\section{THE TESTA LINE OF CASES}

The first of the two lines of cases we relied upon is most closely associated with the Supreme Court's decision in Testa v. Katt. ${ }^{7}$ In Testa, the Court held that the Supremacy Clause requires state courts to entertain federal claims if they have jurisdiction to entertain analogous state-law claims. ${ }^{8}$ In other words, state jurisdictional rules cannot discriminate

\footnotetext{
* Scott K. Ginsburg Professor of Law, Georgetown University Law Center.

** A. Dalton Cross Professor in Law, The University of Texas at Austin School of Law.

1. 136 S. Ct. 718 (2016).

2. Montgomery, 136 S. Ct. at $729,731$.

3. See id. at 732 .

4. Carlos M. Vázquez \& Stephen I. Vladeck, The Constitutional Right to Collateral PostConviction Review, 103 VA. L. ReV. 905, 929 (2017).

5. See, e.g., Ann Woolhandler \& Michael G. Collins, State Jurisdictional Independence and Federal Supremacy, 72 FLA. L. REV. 73, 76-77, 105 n.185, 114, 116 (2020).

6. E.g., id. at 85-86, 92.

7. 330 U.S. 386 (1947).

8. Testa, 330 U.S. at 394.
} 
against federal claims. Under this standard, whether state courts are required to entertain an action seeking collateral relief on the basis of the federal claim recognized in Montgomery depends on what counts as an analogous state-law claim. At a minimum, a state would have to provide a forum for a Montgomery claim if the state gives its courts jurisdiction to entertain actions for collateral relief on the basis of retroactively applicable new rules of state constitutional law. But the concept of an analogous state-law claim could be drawn at a broader level, requiring state courts to entertain a Montgomery claim if they have jurisdiction to entertain claims for collateral relief on the basis of any state constitutional claim, or even on any non-constitutional state-law ground. There is language in Montgomery suggesting that the Court understood the concept of an analogous state-law claim broadly. ${ }^{9}$ For instance, the Court stated that state courts were obligated to entertain the type of claim involved in Montgomery at least as long as "state collateral review proceedings permit prisoners to challenge the lawfulness of their confinement."10

We argued that the Court in Haywood v. Drown ${ }^{11}$ adopted an even broader view of the states' obligation to provide a forum for federal claims. ${ }^{12}$ The issue in Haywood was whether New York could convert all damages claims against corrections officers into claims against the state itself in its Court of Claims - the effect, but not intent, of which would be to foreclose claims under 42 U.S.C. $\S 1983$, which the Supreme Court has interpreted not to authorize suits against states. ${ }^{13}$ The Court did not explicitly reject the idea that the states' obligation to provide a forum for such claims depends on whether those states give their courts jurisdiction over analogous state-law claims, but it interpreted the concept of an "analogous" state-law claim very broadly. ${ }^{14}$ The majority concluded that the Supremacy Clause required New York to make its courts available for federal damages claims against corrections officers because New York courts were open to damages claims against other state officials and equitable claims against corrections officials. ${ }^{15}$ More generally, the Court relied on the fact that the states' courts are courts of general jurisdiction generally open to claims in law and equity. ${ }^{16}$ We argued that the Court's reasoning supported the conclusion that a state court is required to grant

9. Montgomery v. Louisiana, 136 S. Ct. 718, 731-32 (2016).

10. Id. at 731. But cf. id. at 731 ("If a state collateral proceeding is open to a claim controlled by federal law, the state court 'has a duty to grant the relief that federal law requires."' (quoting Yates v. Aiken, 484 U.S. 211, 218 (1988))).

11. 556 U.S. 729 (2009).

12. Vázquez \& Vladeck, supra note 4, at 933-34.

13. See Haywood, 556 U.S. at 731,734 n.4 (citation omitted).

14. Id. at 740 n.6 (citation omitted).

15. Id. at 736-37.

16. See id. at 739. 
state prisoners a forum in which to seek collateral relief on the grounds recognized in Montgomery as long as their courts have jurisdiction to grant equitable relief from ongoing violations of law. ${ }^{17}$ If the fact that a states' courts have jurisdiction over claims "at law" means that those courts must entertain federal claims for damages against state correction officials, then it follows that a states' courts are required to grant relief from ongoing unconstitutional incarceration if they have jurisdiction to grant prospective relief from ongoing unlawful conduct. ${ }^{18}$ Habeas relief, after all, is just one type of prospective relief from an ongoing unlawful detention. ${ }^{19}$

Professors Woolhandler and Collins do not quarrel with our interpretation of Testa or Haywood.$^{20}$ Rather, they dispute the correctness of these decisions, arguing that a requirement that state courts entertain federal claims - even if they have jurisdiction over analogous state-law claims - is not supported by the original understanding of the Constitution and conflicts with nineteenth-century Supreme Court decisions. ${ }^{21}$ We did not attempt to defend the principle established in the Testa line of cases as required by the original understanding or earlier judicial decisions, and we will not attempt a comprehensive defense here. Instead, we will limit ourselves to a few observations.

First, with respect to the original understanding of the Constitution, while there may not have been affirmative statements by the Framers that state courts were obligated to entertain federal claims, the position eventually adopted in Testa and Haywood is more consistent with a key feature of the original design - the Madisonian Compromise - than is the position advocated by Professors Woolhandler and Collins. The Framers were divided about whether the Constitution should create lower federal courts or should instead provide only for a federal Supreme Court. Notably, the latter was the regime supported by the Framers most protective of state prerogatives. ${ }^{22}$ As Professors Woolhandler and Collins recognize, if this view had prevailed, the Constitution would, of necessity, have required state courts to entertain federal causes of action, as there would not have been lower federal courts in which to adjudicate

17. Vázquez \& Vladeck, supra note 4, at 913-14.

18. Id. at 933 .

19. See, e.g., Ex parte Young, 209 U.S. 123, 159 (1908), discussed in Vázquez \& Vladeck, supra note 4, at 933.

20. See Woolhandler \& Collins, supra note 5, at 75 ("In Haywood v. Drown, . . the Court extended the Testa line by holding that even a nondiscriminatory state jurisdictional rule was not a valid excuse for denying jurisdiction over a federal statutory claim if the state's rule evinced hostility to the substantive federal claim.").

21. See id. at 78.

22. See Richard H. Fallon, Jr. et al., Hart and Wechsler's The Federal Courts and THE FEDERAL SyStem 7-9 (7th ed., 2015). 
federal rights. $^{23}$ The Framers ultimately adopted the Madisonian Compromise, under which the Constitution created only a Supreme Court and left it to Congress to decide whether to create lower federal courts. ${ }^{24}$ The default regime established by the Constitution, therefore, was one in which enforcement of federal law mainly depended on state courts. Professors Woolhandler and Collins claim that the requirement that state courts entertain federal claims did not survive the Framers' decision to empower Congress to create lower federal courts. ${ }^{25}$ But, if they are right, the Madisonian Compromise would have been all but illusory. In theory, Congress would have had the power to decline to create lower federal courts, but it would have been able to exercise this power only in the unlikely event that it decided not to create any federal claims.

Moreover, Professors Woolhandler and Collins would adopt, in the name of states' rights, a position that conflicts with the apparent preferences of the Framers most concerned about states' rights. Professors Woolhandler and Collins maintain that, if Congress wants to create judicially enforceable federal rights that do not depend upon the whims of state legislatures, Congress has to create lower federal courts and give them jurisdiction over such claims. ${ }^{26}$ But the Framers who most wished to protect state prerogatives believed it would have been more protective of states' rights to vest jurisdiction over such claims in the state courts than to have the Constitution create lower federal courts. ${ }^{27}$ In other words, states' rights advocates presumably would have preferred to have federal claims enforced in state courts, subject to Supreme Court review, than to have Congress create lower federal courts and vest jurisdiction over such claims in such courts.

Professors Woolhandler and Collins do not address these arguments in their article but, in earlier work, Professor Collins has defended a "revisionist" understanding of the Madisonian Compromise, arguing that the understanding of the Compromise that has prevailed for much of American history is historically inaccurate. ${ }^{28}$ This is not the place to examine Professor Collins's historical claims. For present purposes, it suffices to note that, as Professor Collins candidly admits, acceptance of his views would require a reexamination not just of the Testa line of cases, but also of many other "fundamental tenets of federal courts

23. See Woolhandler \& Collins, supra note 5 , at $80-81$.

24. Id. at 79-80.

25. See id. at 81 .

26. Id. at $84-85$.

27. See supra text accompanying note 22 .

28. See Michael G. Collins, Article III Cases, State Court Duties, and the Madisonian Compromise, 1995 Wis. L. REV. 39, 196 (1995) (describing his view of the Madisonian Compromise as "revisionist"). 
law."29 Moreover, his claims were expressly considered by the Court in Haywood, and only Justice Thomas was convinced to reconsider settled precedents on the basis of these arguments. ${ }^{30}$ Indeed, since the Haywood decision, the Court has unanimously endorsed the Haywood interpretation of the Supremacy Clause rather than the interpretation endorsed by Professors Woolhandler and Collins. ${ }^{31}$

Not all of the cases that Professors Woolhandler and Collins now rely upon were brought to the Court's attention in Haywood. Most notably, Professors Woolhandler and Collins rely on nineteenth-century Supreme Court decisions dismissing appeals from the state courts on the ground that the state court had held that it lacked jurisdiction over the case. ${ }^{32}$ These decisions are not inconsistent with Testa or Haywood, however, as they did not involve federal rights of action. Federal statutes did lurk in the background of these cases, but the claimants raised common law rights of action. Semple v. Hagar ${ }^{33}$ was an action to quiet title in real property. ${ }^{34}$ In Smith v. Adsit, ${ }^{35}$ the plaintiff filed a bill in equity seeking

29. Id. at 39. Indeed, acceptance of Professors Woolhandler and Collins' argument would require reconsideration of settled doctrine outside the Federal Courts field. See, e.g., Ann Woolhandler \& Michael G. Collins, Jurisdictional Discrimination and Full Faith and Credit, 63 EMORY L.J. 1023, 1028 (2014) (arguing on similar grounds that the holding of Hughes v. Fetter regarding state court obligation under the Full Faith and Credit Clause to entertain causes of action based on sister state law was wrong).

30. Haywood v. Drown, 556 U.S. 729, 748 n.2 (2009) (Thomas, J., dissenting) (referencing Collins, supra note 28, at 144). Chief Justice Roberts and Justice Alito joined Justice Thomas's dissent (as to Part III) insofar as it concluded that state courts were not required to exercise jurisdiction over federal claims if they lacked jurisdiction over analogous state-law claims. Id. at 742. They did not join the portion of Justice Thomas's dissent adopting the view of Professors Woolhandler and Collins that state courts are not required to entertain federal claims even if those courts have jurisdiction over analogous state-law claims. $I d$.

31. See Mims v. Arrow Fin. Servs., LLC, 565 U.S. 368, 382 n.12 (2012). Mims involved a federal statute establishing a private right of action under the Telephone Consumer Protection Act (TCPA) and provided that the action may be brought in state court "if otherwise permitted by the laws or rules of court of [the] State." Id. at 382 (citing 47 U.S.C. $§ 227(b)(3)$ (2012)). In Mims, the Court wrote:

The Supremacy Clause declares federal law the "supreme law of the land," and state courts must enforce it "in the absence of a valid excuse." Howlett v. Rose, 496 U.S. 356, 370, n. 16 (1990). "An excuse that is inconsistent with or violates federal law is not a valid excuse: The Supremacy Clause forbids state courts to dissociate themselves from federal law because of disagreement with its content or a refusal to recognize the superior authority of its source." Id., at 371 . Without the "if otherwise permitted" language, there is little doubt that state courts would be obliged to hear TCPA claims. See Testa v. Katt, 330 U.S. 386, 394 (1947).

Mims, 565 U.S. at 382 n. 12 .

32. Woolhandler \& Collins, supra note 5, at 88-90.

33. 71 U.S. (4 Wall.) 431 (1866).

34. Semple, 71 U.S. (4 Wall.) at 432.

35. 83 U.S. (16 Wall.) 185 (1872). 
an accounting and the establishment of a trust based on allegations of fraud. ${ }^{36}$ In support of an alternative argument, the plaintiff invoked a federal statute that declared certain warrants to be nullities, ${ }^{37}$ but the statute was not the source of his right of action. The Supreme Court concluded that it was unclear that the lower court had even relied on the statute in reaching its judgment. ${ }^{38}$ Further, it surmised that the higher state court may well have concluded that the lower court lacked jurisdiction because "the plaintiff's remedy against Adsit was at law, and not in equity, even if the sale from Holmes to him was utterly void." ${ }^{39}$ In neither case does the Court's acceptance of the state court's determination that it lacked jurisdiction establish that the state court would have been equally free to dismiss federally created rights of action.

Professors Woolhandler and Collins also argue that requiring state courts to entertain federal claims would amount to commandeering state courts in contravention of the Tenth Amendment's anti-commandeering doctrine. ${ }^{40}$ But whether the Constitution prohibits commandeering of state officials is itself controversial. More importantly, even the Justices who concluded that the Constitution prohibits commandeering of state legislative and executive officials acknowledged that the Constitution permits commandeering of state judicial officials. ${ }^{41}$ Indeed, the Court in Printz v. United States ${ }^{42}$ exempted state judicial officials from the anticommandeering prohibition because the Supremacy Clause expressly contemplates such commandeering. ${ }^{43}$ The debate among the Justices in the anti-commandeering cases concerned whether the Constitution prohibits commandeering of state legislative and executive officials, and the Supremacy Clause, as interpreted in Testa, was put forward as a basis for rejecting the anti-commandeering doctrine altogether. ${ }^{44}$ The majority ultimately distinguished Testa on the ground that the Supremacy Clause draws a distinction between state judges and other state officials. ${ }^{45}$ That the Constitution does not prohibit commandeering of state judges

36. See Smith, 83 U.S. (16 Wall.) at 186-87; see also Smith v. Adsit, 90 U.S. (23 Wall.) 368, 369 (1874).

37. See Smith, 83 U.S. (16 Wall.) at 186.

38. Id. at 190.

39. Id.

40. See Woolhandler \& Collins, supra note 5, at 101.

41. See Printz v. United States, 521 U.S. 898, 907 (1997) (recognizing "that the Constitution was originally understood to permit imposition of an obligation on state judges to enforce federal prescriptions, insofar as those prescriptions related to matters appropriate for the judicial power").

42. 521 U.S. 898 (1997).

43. U.S. Const. art. VI, cl. 2 ("This Constitution, and the Laws of the United States which shall be made in Pursuance thereof; and all Treaties made, or which shall be made, under the Authority of the United States, shall be the supreme Law of the Land; and the Judges in every State shall be bound thereby ....") (emphasis added); see Printz, 521 U.S. at 907.

44. See Printz, 521 U.S. at 928-29.

45. See id. 
performing judicial functions was common ground in the anticommandeering cases.

Finally, it is worth observing that there is more than a little irony in the argument by Professors Woolhandler and Collins that state courts are not obligated to entertain Montgomery claims because the Testa/Haywood line of cases is inconsistent with earlier Supreme Court decisions. Montgomery holds that prisoners have a right to relief from continued imprisonment if their convictions or sentences contravene a retroactively applicable new rule of constitutional law. ${ }^{46}$ The very existence of "new" rules of constitutional law is a clear acknowledgment that the Court recognizes - and presumably adheres to-constitutional decisions even if the rules established in those decisions lack clear support in earlier constitutional decisions. ${ }^{47}$

\section{THE CRAIN LINE OF CASES}

In arguing that state courts are required to provide a forum in which a state prisoner can seek collateral relief from retroactively applicable new rules of constitutional law, we noted that a separate line of Supremacy Clause decisions provided even more direct support: the line of cases most closely associated with General Oil Co. v. Crain. ${ }^{48}$ Crain held that a state law denying its courts jurisdiction to grant a remedy that is required by the Constitution is not an "adequate" state ground preventing direct review in the Supreme Court. ${ }^{49}$ It follows that state courts are required to provide constitutionally required remedies even if those courts lack jurisdiction to do so under state law. Crain supports our conclusion that state courts must provide the remedy recognized in Montgomery even more directly than does the Testa line of cases because Montgomery involved a constitutionally required remedy while the Testa line of cases involved federal statutory rights of action. ${ }^{50}$

Professors Woolhandler and Collins argue that the original understanding of the Constitution and nineteenth-century caselaw are as inconsistent with the Crain line of cases as with the Testa line of cases. ${ }^{51}$ But their position regarding constitutionally required remedies is even less plausible from the perspective of constitutional structure than their position with respect to federal statutory claims. When Congress creates

46. Montgomery v. Louisiana, 136 S. Ct. 718, 729-31 (2016).

47. See Teague v. Lane, 489 U.S. 288, 301 (1989) ("In general, . . . a case announces a new rule when it breaks new ground or imposes a new obligation on the States or the Federal Government.").

48. 209 U.S. 211 (1908), nonacq. Carson Petroleum Co. v. Vial, 279 U.S. 95 (1929); see Vázquez \& Vladeck, supra note 4, at 937.

49. Crain, 209 U.S. at 226-27.

50. See supra notes 43-44, 49 and accompanying text.

51. Woolhandler \& Collins, supra note 5, at 93 \& n.129. 
a right of action, it can be expected to give the lower federal courts jurisdiction over such claims if state courts are not constitutionally obligated to entertain those claims. But the availability of a constitutionally required remedy should not depend on a congressional decision to confer jurisdiction on the lower federal courts. By hypothesis, such remedies should be available even if Congress does not favor them. For this reason, the Crain line of cases stands on even firmer ground as a matter of constitutional structure than the Testa line of cases. ${ }^{52}$

Perhaps in silent recognition of the force of this structural argument, the treatment of Crain by Professors Woolhandler and Collins differs from their treatment of Testa and Haywood. Instead of arguing that Crain should be rejected entirely, they argue that Crain should be understood to require state courts to enforce constitutional remedies only when federal court jurisdiction to grant such remedies is either lacking or "disfavored." 53 They claim that this more limited requirement is consistent with the caselaw.

It is difficult to draw such a limited standard from Crain itself, however, as the Court decided Ex parte Young on the same day, and the Young decision appears to hold that federal courts do have the power to grant the constitutionally required remedy involved in Crain. ${ }^{54}$ Professors Woolhandler and Collins contend that, on the facts of Crain, federal jurisdiction to grant the relief involved in that case "may have been less than clear . . . even after the decision in Young." 55 If that is how they reconcile their position with Crain, however, their position would have to be that state courts are obligated to grant constitutionally required remedies if federal jurisdiction is lacking or disfavored or unclear. ${ }^{56}$

52. See Vázquez \& Vladeck, supra note 4, at 936 ("The conclusion that the state courts must entertain federal claims, subject only to neutral rules of administration that do not reflect hostility to the right, stands on an even stronger footing when the federal claim seeks a constitutionally required remedy.").

53. Woolhandler \& Collins, supra note 5, at 113.

54. See Ex parte Young, 209 U.S. 123, 176 (1908) (Harlan, J., dissenting).

55. Woolhandler \& Collins, supra note 5, at 110-11.

56. See id. Professors Woolhandler and Collins also rely on Ga. R.R. \& Banking Co. v. Musgrove, 335 U.S. 900 (1949) (per curiam), in which the Supreme Court summarily dismissed the appeal for lack of appellate jurisdiction, stating that the state court's decision had rested on an adequate state law ground. Musgrove, 335 U.S. at 900 . When contrasted with the Court's later determination that the railroad's suit could be brought in the lower federal courts, see Ga. R.R. \& Banking Co. v. Redwine, 342 U.S. 299, 304, 306 (1952), Professors Woolhandler and Collins argue, the summary dismissal in Musgrove reflects the Court's view that states are free to deny their courts' jurisdiction over constitutionally required remedies if lower federal courts are available to grant such remedies. Woolhandler \& Collins, supra note 5, at 111 . It is difficult to know the Supreme Court's rationale in Musgrove as the Court did not explain its reasoning, but to read the decision as standing for the principle advocated by Professors Woolhandler and Collins is a stretch. The state court in Musgrove determined that the state was entitled to sovereign 
Under that standard, state courts would appear to be required to entertain claims for the form of collateral relief involved in Montgomery, as we argued. ${ }^{57}$ Montgomery held that prisoners are constitutionally entitled to collateral relief if those prisoners' convictions or sentences contravene a retroactively applicable new rule of constitutional law. ${ }^{58}$ Whether federal courts have jurisdiction to grant habeas relief in such cases is unsettled. The Antiterrorism and Effective Death Penalty Act of 1996 (AEDPA) provides that the federal courts lack the power to grant habeas relief if the petitioner's claim was adjudicated on the merits in state court unless the state court's "adjudication of the claim resulted in a decision that was contrary to, or involved an unreasonable application of, clearly established Federal law, as determined by the Supreme Court of the United States." 59 The text of the statute appears to deny the federal courts the power to grant relief based on federal law that was not clearly established at the time of conviction if the claim was adjudicated on the merits at trial. One could argue that AEDPA should be read to permit such claims, notwithstanding the text, and we have argued that AEDPA should be so interpreted. ${ }^{60}$ The Supreme Court itself has acknowledged that possibility but, so far, the Court has left the question open. ${ }^{61}$ If AEDPA obligates state courts to afford constitutionally required remedies as long as federal power to grant those remedies is unclear, then

immunity from the railroad's suit and it relied on federal as well as state precedents. Musgrove v. Ga. R.R. \& Banking Co., 49 S.E.2d 26, 38 (Ga. 1948), appeal dismissed, 335 U.S. 900 (per curiam). The court acknowledged that Ex parte Young held that a suit against a state official seeking prospective relief from an ongoing violation of the Constitution is not a suit against the state. Id. at 36. But, relying on In re Ayers, 123 U.S. 443 (1887), the court held that the Ex parte Young principle did not apply when the plaintiff seeks to enforce a contract with the state. Musgrove, 49 S.E.2d at 36-37. After the Supreme Court dismissed its appeal, the railroad filed an action in federal court that did not seek specific performance of its contract with the state, and the Court held that the state was not entitled to sovereign immunity. See Redwine, 342 U.S. at 305 (interpreting Ayers as extending only to cases in which the plaintiff "merely [seeks] to obtain specific performance of a contract with the State"). The divergent results in the two casesMusgrove and Redwine - thus appear to have been based on the different forms of relief sought. There is no hint in either Supreme Court opinion that the Court understood that a state could deny its courts' jurisdiction over constitutionally required remedies when a federal forum is available. The state court's reliance in Musgrove on federal precedents about when a suit against an officer is actually against the state tends to contradict such a reading.

57. Vázquez \& Vladeck, supra note 4, at 913-14.

58. Montgomery v. Louisiana, 136 S. Ct. 718, 729, 731 (2016).

59. 28 U.S.C. $\$ 2254(d)(1)(2018)$.

60. Vázquez \& Vladeck, supra note 4 , at $938,944$.

61. See Greene v. Fisher, 565 U.S. 34, 39 n.* (2011). Justice Scalia's dissenting opinion in Montgomery mentions that this issue is unresolved. See Montgomery v. Louisiana, $136 \mathrm{~S}$. Ct. 718, 741 (2016) (Scalia, J., dissenting). Amici in Edwards v. Vannoy have urged the Court to resolve the question this Term, even though it is not one of the questions on which the Court has granted certiorari. See Brief for Jonathan F. Mitchell and Adam K. Mortara, as Amici Curiae Supporting Neither Party at 14, Edwards v. Vannoy, No. $19-5807$ (argued Dec. 2, 2020). 
it obligates state courts to grant the constitutionally required remedy recognized in Montgomery if the claim was adjudicated on the merits at trial, at least until the Supreme Court resolves the question it has thus far left open.

Even if the Court resolves that question in favor of the existence of federal jurisdiction, state courts might still be required to grant the remedy on the ground that federal jurisdiction over such claims is "disfavored." Professors Woolhandler and Collins argue that federal jurisdiction over a class of cases is "disfavored" when a federal statute, or federal caselaw, "substantially direct[s]" that the particular category of cases be brought in the state courts, even if the federal courts are given jurisdiction over the claims. ${ }^{62}$ It is unclear what sort of preference for state court adjudication Professors Woolhandler and Collins believe would trigger a state court obligation to grant such a remedy, but it seems likely that AEDPA would suffice. The general habeas regime for state prisoners reflects a preference for adjudicating these claims in state courts, ${ }^{63}$ and AEDPA itself appears to buttress that preference in a variety of ways. ${ }^{64}$

Even if the Court interpreted AEDPA to permit federal habeas relief in cases based on retroactively applicable new rules of constitutional law-and even if federal jurisdiction over such claims were not deemed to be "disfavored" in the sense contemplated by Professors Woolhandler and Collins - state courts would still be constitutionally obligated to grant such relief in circumstances in which AEDPA's procedural rules would impose limits on federal jurisdiction that would be unconstitutional if imposed by states on state courts. For instance, we argued that AEDPA's restrictions on "second or successive" petitions could violate the Due Process Clause if applied by state courts to claims based on retroactively applicable new rules of constitutional law. ${ }^{65} \mathrm{We}$ concluded, based on the traditional understanding of the Madisonian Compromise, that AEDPA's imposition of these procedural rules on the federal courts would probably not be unconstitutional because federal jurisdiction is constitutionally optional and state courts are obligated to grant the constitutionally required relief. ${ }^{66}$ Because Professors Woolhandler and Collins accept that state courts are obligated to grant the required relief if federal courts lack jurisdiction to grant it, they would appear to agree with our conclusion

62. Woolhandler \& Collins, supra note 5, at 112-13.

63. For example, state prisoners are required to exhaust available state court remedies prior to filing a habeas petition. See FALlon, JR. ET AL., supra note 22, at 1349-50 (describing the Exhaustion Requirement).

64. See supra note 61 (quoting 28 U.S.C. $§ 2254(\mathrm{~d})$ ); see also FALLON, JR., ET AL., supra note 22, at 1320 (noting AEDPA's deference to state courts).

65. See Vázquez \& Vladeck, supra note 4, at 956-57.

66. See id. at 957. 
that state courts are constitutionally obligated to provide collateral review for state prisoners based on retroactively applicable new rules of constitutional law when Congress has imposed limits on the federal courts' power to grant such relief that would violate the Due Process Clause if imposed by the states on state courts.

Professors Woolhandler and Collins argue that, even if state courts are obligated to provide constitutionally required remedies when federal court jurisdiction over such claims is lacking, disfavored, or unclear, the state courts do not have to "entertain the very same cause of action that the federal courts would have entertained." 67 We entirely agree. The express form of the remedy is not conclusive. We insist only that state courts are required to provide $a$ collateral remedy that meets the minimum constitutional requirements. States need not call their remedies "habeas actions," and states can impose their own procedural rules, as long as they satisfy federal due process limits. Indeed, our claim is that the state courts' obligation to provide remedies meeting due process standards saves federal jurisdictional limitations from unconstitutionality. For the same reason, their worry that our position "could entail importing not only what [we] would consider the attractive aspects of federal habeas into state courts but could entail importing federal limitations and other complexities as well" is misplaced. ${ }^{68}$ Recognizing state courts' obligations to supply constitutionally required remedies in no way discourages states from providing constitutionally optional remedies or from experimenting with different procedures. ${ }^{69}$

In any event, Professors Woolhandler and Collins's acceptance that state courts are obligated to provide constitutionally required remedies if federal jurisdiction is lacking or disfavored or unclear shows that their position with respect to constitutional remedies is very different from their position regarding federal statutory causes of action, even though both are, in their view, equally unsupported by the original understanding of the Constitution and nineteenth-century caselaw. With respect to constitutionally required remedies, state courts' obligations depend entirely on Congress' preferences. Professors Woolhandler and Collins agree with us that Congress can deny state courts' jurisdiction by making federal jurisdiction exclusive, and they admit that Congress can require state courts to grant constitutionally required remedies by denying jurisdiction to federal courts or even by "disfavoring" federal jurisdiction. ${ }^{70}$ The difference between our positions thus appears to be

67. Woolhandler \& Collins, supra note 5, at 113.

68. Id. at 122 .

69. See, e.g., Danforth v. Minnesota, 552 U.S. 264, 275 (2008) ("Neither Linkletter nor Teague explicitly or implicitly constrained the authority of the States to provide remedies for a broader range of constitutional violations than are redressable on federal habeas.").

70. Woolhandler \& Collins, supra note 5, at 85-86, 116. 
about the circumstances in which a congressional grant of federal court jurisdiction should be interpreted as an implicit withdrawal of state court jurisdiction. Our disagreement is thus, in the end, merely about statutory interpretation. This is hardly a profound debate about the Constitution's protection of state jurisdictional independence.

We think our position - that state courts retain an obligation to provide constitutionally required remedies unless Congress has expressly, or by clear implication, conferred exclusive jurisdiction on the federal courts - is far more administrable. Perhaps more importantly, we think our view is more compatible with the understanding of the Madisonian Compromise that has prevailed for much of American history and has, during that time, been the basis of numerous canonical Supreme Court decisions vis-à-vis the relations between state and federal courts. The arguments put forward by Professors Woolhandler and Collins, on the other hand, would require a rethinking not just of Testa and Haywood and Crain, but also of large swaths of Federal Courts doctrine. 